\title{
P01-002 - Comparison between different colchicines responders
}

\author{
ZB Özçakar ${ }^{1 *}$, AH Elhan², F Yalcinkaya ${ }^{1}$ \\ From 7th Congress of International Society of Systemic Auto-Inflammatory Diseases (ISSAID) \\ Lausanne, Switerland. 22-26 May 2013
}

\section{Introduction}

Familial Mediterranean fever (FMF) is an autosomal recessive disease, characterized by recurrent, self-limited attacks of fever with serositis involving the peritoneum, pleura and joints; and colchicine is its universal treatment.

\section{Objectives}

To explore whether the demographic and clinical features of FMF patients with different colchicine response vary or not.

\section{Methods}

Files of patients who had been seen in our department (during routine follow-up visits) between January 2009 and January 2013 were retrospectively evaluated.

\section{Results}

The study group comprised 221 FMF patients (116F, $105 \mathrm{M})$ with a mean age of $12.7 \pm 5.3$ years. Mean duration of colchicine use was $58.9 \pm 45.3$ months. Patients were divided into two groups according to their colchicine response; Group I $(n=131)$ included patients with no attacks after colchicine and Group II $(n=90)$ patients with partial or no response to colchicine. Mean age, sex, age at disease onset, age at colchicine onset, family history of FMF, attack frequency, attack duration, clinical features during attacks, duration of colchicine use and M694V carriage were similar between the groups. Final colchicine doses, disease severity scores, acute phase reactant levels (during attack free period) were significantly higher in Group II when compared with those of Group I $(\mathrm{p}<0.5)$.

${ }^{1}$ Ankara University, Pediatric Rheumatology, Turkey

Full list of author information is available at the end of the article

\section{Conclusion}

Colchicine response seems to be related with disease severity scores and acute phase reactant levels (during attack free periods) in FMF patients.

\section{Disclosure of interest}

None declared.

Authors' details
'Ankara University, Pediatric Rheumatology, Turkey. ${ }^{2}$ Biostatistics, Ankara
University, Ankara, Turkey.

Published: 8 November 2013

doi:10.1186/1546-0096-11-S1-A6

Cite this article as: Özçakar et al.: P01-002 - Comparison between

different colchicines responders. Pediatric Rheumatology 2013 11(Suppl 1): A6.
Submit your next manuscript to BioMed Central and take full advantage of:

- Convenient online submission

- Thorough peer review

- No space constraints or color figure charges

- Immediate publication on acceptance

- Inclusion in PubMed, CAS, Scopus and Google Scholar

- Research which is freely available for redistribution 